\title{
Yoğun Bakım Hastalarında Duyusal Girdi Sorunları ve Hemşirelik Yaklaşımı
}

\author{
Sensory Input Problems of Intensive Care Patients and Nursing Approach
}

\author{
Derya UZELLI*, Esra AKIN KORHAN**
}

İletişim/Correspondence: Derya UZELLİ Adres/Adress: Tepecik Eğitim ve Araştırma Hastanesi Konak/İzmir Tel: 0-232-3739352

Fax: 0-232-3800888 E-mail: deryauz.86@hotmail.com

\section{$\ddot{O} Z$}

Yoğun bakım üniteleri tedavi yöntemleri, teknik donanımı, fiziksel görünümü ve duyusal çevresi açısından hastanenin diğer bölümlerinden farklı olan özel ünitelerdir. İleri teknolojik gelişmelerin kullanıldĭ̆ y yoğun bakım üniteleri yaşam

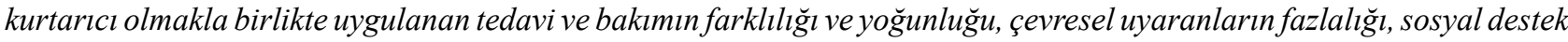
sistemlerinin eksikliği gibi nedenler ile hastalarda duyusal yoksunluk ve duyusal yüklenme gibi duyusal değişikliklerin ortaya çıkmasına zemin hazırlamaktadır. Bu nedenle yoğun bakım ünitesinde tedavi görmekte olan hastaların bakım ve tedavi gereksinimleri karşılanırken fiziksel gereksinimlerin yanı sira psikososyal gereksinimlerinin de göz ardı edilmediği holistik bakış açısı ile sunulan hemşirelik bakımı anlamlı ve önemlidir. Bu derlemede amaç yoğun bakım hastalarının deneyimlediği duyusal girdi sorunlarına dikkat çekmek ve bu doğrultuda verilebilecek hemşirelik yaklaşımlarını açılklamaktır.

Anahtar Kelimeler: Yoğun bakım ünitesi, duyusal girdi, duyusal yoksunluk, hemşirelik, yoğun bakım hastasl.

\section{ABSTRACT}

Intensive care units are special units that differ from other units of the hospital in terms of its treatment methods, technical equipment, physical appearance and sensory environment. Intensive care units that the advanced technological developments used in set the stage for appearing of sensory changing such as sensory deprivation and sensory pressure for patients by the reasons such as difference and intensity of the treatment, extra environmental stimulus, and lack of social support systems as well as being lifesaving. That's why, while meeting the care and treatment requirements of intensive care patients, a holistic nursing care in which the patients' psychosocial requirements are not ignored as well as their physical requirements is meaningful and important. In this article, writers aim to attract attention to the sensory input problems that the intensive care patients experienced and to explain nursing approaches that can be served in this direction.

Key Words: Intensive care unit, sensory input, sensory deprivation, nursing, intensive care patients.

\section{GíRíș}

Sağlık; fiziksel, ruhsal ve sosyal boyutları ile bir bütündür ve her boyut birbirini etkiler (Kaçmaz 2002). Yaşam süresince bireyler, zaman zaman sağlıklı olma du- rumundan uzaklaşarak tedavi ve bakımı gerekli kılan hastalık durumu ile karşı karşıya gelmektedirler (Kutlu 2010). Bozulan dengenin düzenlenmesi, bireyin fizyolojik, psikolojik ve sosyal sağlı̆̆ına kavuşabilmesi için hastaneye yatması gerekebilir (Kutlu 2010).

\footnotetext{
*Uzman Hemşire Tepecik Ĕgitim ve Araştırma Hastanesi, ${ }^{* *}$ Yard. Doç. Dr. İzmir Katip Çelebi Üniversitesi Sağlık Bilimleri Fakültesi
} 
Yoğun bakım üniteleri (YBÜ), fiziksel durumu ağır olan hastaların monitör ile izlenerek yaşam fonksiyonlarının desteklendiği, özel tedavi yöntemlerinin uygulandığı, karmaşık cihazların bulunduğu, önemli ölçüde dikkat gerektiren bölümlerdir (Arslan ve Özer 2010; Demir ve Dramal1 2002; Fontaine, Briggs ve Pope-Smith 2001). Hastaların yaşamsal işlevleri risk taşıyacak derecede bozulduğunda, yaşam işlevlerinin sürdürülmesi ve özel tedavi yöntemlerinin uygulanması için YBÜ'de tedavi görmeleri gerekir. YBÜ, tedavi yöntemleri, teknik donanımı, fiziksel görünümü ve duyusal çevresi açısından hastanenin diğer bölümlerinden farklıdır. Yaşamın tehdit altında olması, alışı olunmayan çevre ve kişiler, hareket kısıtlılığı, yatağa bağımlı olma, yakınlarını ve ailelerini görememe, araçlara veya yoğun bakım ünitesine bağımlılık duygusu, sık tekrarlanan ağrılı girişimler, hastalık, tedavi ve uygulamalar hakkında yeterince bilgilendirilmeme gibi faktörler psiko-sosyal sorunların ortaya çıkmasına neden olmaktadır (Arslan 2007; Çınar 2010; Dedeli ve Akyol 2008). Hastal1k ya da yaralanma beden üzerinde önemli bir fizyolojik stres oluşturur (Fontaine ve ark. 2001). Ancak YBÜ ortamında başka stresörler de vardır. YBÜ'de aşırı gürültü, 1şık, trafik yoğunluğu gibi çok sayıda istenmeyen uyaranlar olabildiği gibi, bazı tıbbi araç-gereçten çıkan tekdüze sesler, hareketsizlik, sessizlik gibi duyusal uyaranların az olduğu durumlar da olabilir (Çınar 2010; Kutlu 2010; Mollaoğlu 1997). YBÜ'de bulunan ileri teknolojik araç-gereç yaşam kurtarıcı olmakla birlikte, hasta için ürkütücü olabilir ve hastaların çevreyi yabancı olarak algılamalarına neden olabilir (Fontaine ve ark. 2001; Kaçmaz 2002; Kutlu ve Yıldırım 2001). Yaşamı tehdit altında olan hastaların kritik durumlarını kavramaları, monitörizasyon, ventilatör, infüzyon setleri, idrar sondası gibi nedenlerden dolay1 hareket kısitlllığı, temporal ritmin (Bellek, öğrenme, duygusal denge ve sosyalleşme konuları temporal bölgenin çalışması sonucu ortaya çıkan özelliklerdir) ve gece-gündüz ayrımının kaybedilmesi, izolasyon sık tekrarlanan ağrılı manipülasyonlar, alışık olunmayan çevre ve kişiler ajitasyona neden olmaktadır (Ç1nar 2010; Kutlu ve Yıldırım 2001). Ayrıca yoğun ba- kım temposu içinde uyku düzeninin bozulması, çeşitli tıbbi araç-gerecin monoton sesleri, yakınlarını ve ailelerini görememe, araçlara veya yoğun bakım ünitesine bağımlılık duygusu, uygulanan tedavi ve işlemler, tedavi ve uygulamalar hakkında yeterince bilgilendirilmeme gibi faktörler de hastalarda ajitasyon, anksiyete, depresyon, dizoryantasyon, deliryum gibi çeşitli psikolojik semptomların ortaya çıkmasına neden olmaktadır. Yoğun bakım ortamında etkili ve iyi iletişim kurulması ve gereksinimlerin karşılanması hastaların tedavi ve bakım kalitesinin yükselmesinde etkili olduğu gibi hasta psikolojisini de olumlu etkileyecektir (Çınar 2010).

Yapılan çalışmalarda, hareket ve vücut duruşundaki k1sitlılığın ve sosyal izolasyonun YBÜ'de duyusal yoksunluğa, insan seslerinin, entübasyonun, ağr111 girişimlerin duyusal yüklenmeye neden olduğu, her iki duyusal girdi sorununun da YBÜ'de yatan hastalarda bilişsel fonksiyonlarda azalma, huzursuzluk, saldırganlık, uyku-uyanıklılık döngüsünde bozulma, oryantasyon bozukluğu belirtileri ile ortaya çıkan YBÜ sendromu gelişmesine yol açtığ 1 saptanmıştır (Dedeli ve Akyol 2005; Hunt 1999).

\section{Duyu ve Duyusal Girdiler}

Duyu, çevre hakkında bilgi sahibi olma yolu ya da arac1dır. Alg1 ise, duyu organları yoluyla nesnelerin nitelik ve ilişkilerinin farkında olma sürecidir. Duyusal girdi; çevremizden gelen ve algıladığımız uyaranlardır. Duyusal algılama ise kısaca, görme, işitme, koku alma, hissetme duyularının uyarılmasıdır ve duyusal girdilerin nicelik ve niteliğinden etkilenir. Sağlık11 insanlar çevredeki uyaranları algıları ile değerlendirerek seçebilirler ve hoşa giden gitmeyen durumları ayırt edip, günlük aktivitelerini buna göre düzenleyebilirler (Arslan 2007; Kutlu ve Yıldırım 2005; Öz 2004). YBÜ'de yatan hastaların çevreden gelen uyarıları seçme şansları ve bunları kontrol etme yetenekleri bulunmamaktadır. Bu nedenle YBÜ'de yatan hastalar daha fazla duyusal girdi sorunları yaşamaktadır (Arslan 2007; Arslan ve Özer 2010; Çınar 2010; Kaçmaz 2002; Kutlu ve Yildırım 2001). 


\section{Duyusal Girdi Sorunları}

Duyusal yoksunluk; Konuşma, görme ve hissetme ile ilgili duyusal kısıtlılık, yalnız başına kalma, izolasyon ve hareket aktivitelerinin kısitlanması gibi duyusal girdinin nitelik ve niceliğindeki azalma duyusal yoksunluk olarak tanımlanır (Çınar 2010; Kutlu ve Y1ldırım 2001; Öz 2004). Beyin sapında bulunan retikular aktive edici sistem (RAS) duyusal uyaranları serebral kortekse iletir. Serebral kortekse iletilen bu uyarılar algılama, öğrenme ve duygulanım için gereklidir. Duyusal uyarılma, uygun nitelik ve nicelikte olursa birey çevre ile iletişimini sürdürebilir. Derin uykuda bilinç düzeyi bozulan hastalar bile uyarıları alabilirler.

Kişinin dış dünya ile uyum içinde yaşayabilmesini sağlayan ego, bilişsel işlevlerin bozulmasıyla etkileneceği için duyusal yoksunluk tablosunda kişinin gerçeği değerlendirme ve normal düşünme yetileri kaybolabilir (Moore 1989). Duyu kayıpları, yaşlılık, hasta ziyaretlerinin kısıtlı ya da hiç olmaması, hasta ile sağlık çalışanlarının yeterli iletişim kurmaması, tek düze uyaranlar, yabancı uyaranlar, uzun süreli hareketsizlik, izolasyon uygulaması, hastanın tek kişilik odada kalması, iyi 1şıklandırılmamış ortamlar duyusal yoksunluk nedenleri arasındadır (Akdemir ve Birol 2003; Arslan 2007; Hewitt 2002; Kaçmaz 2002; Moore 1989).

Duyusal Yüklenme; Duyusal girdilerin niceliğinin artması sonucu ortaya çıan durum ise duyusal yüklenme olarak tanımlanmaktadır. Duyusal yüklenme, girdilerin nitelik ve niceliğinin artması sonucu ortaya çıkan ajitasyon, olayları yanlış algılama, yoğun anksiyete, illüzyon, oryantasyon bozukluğu, hallüsinasyon, konfüzyon gibi semptomları tanımlamaktadır (Çınar 2010; Kaçmaz 2002; Mollaoğlu 1997). Çok sayıda ve alışık olunmayan tıbbi araç gereçler, sık tekrarlanan ağrılı uygulamalar, uzun süre yüksek gürültüye maruz kalma duyusal yüklenmeye neden olmaktadır (Dedeli ve Akyol 2005; Hewitt 2002; Kaçmaz 2002; Yıldırım ve Atalay 1992).

\section{Literatür İncelemesi}

Yoğun bakım üniteleri tedavi yöntemleri, teknik donanımı, fiziksel görünümü ve duyusal çevresi açısından hastanenin diğer bölümlerinden farklıdır. Phipps, Can11 ve Mui So ile Chan tarafından yapılmış araştırmalara ve konuyla ilgili diğer çalışmalara göre, YBÜ'nde aşırı gürültü, 1şık, irrite edici seslerin olduğu uyaranlar gibi strese neden olan durumlar hastalarda duyusal yüklenme, duyusal yoksunluk gibi duyusal değişikliklerin ortaya çıkmasına ve YBÜ sendromunun gelişmesine neden olmaktadır (Canlı 1995; Mollaoğlu 1997; Mui So ve Chan 2004; Öz 2004; Phipps 1991). Bu sorunların yanı sira YBÜ'lerinde yatan hastalarda uykusuzluk, yer ve zaman oryantasyonunda bozulma gibi sorunlar da ortaya çıkabilmektedir (Granberg, Engberg ve Lunberg 1998; Tunçay ve Uçar 2010). Duyusal yoksunluk ve duyusal yüklenme sorunlarının yoğun bakım hastalarında, bilişsel fonksiyonlarda azalma, huzursuzluk, saldırganlık, uyku-uyanıklılık döngüsünde bozulma, oryantasyon bozukluğu belirtileri ile ortaya çıkan YBÜ sendromu gelişmesine yol açtığ belirtilmektedir (Kurlu 2010). Ayrıca yapılan çalışmalarda, yoğun bakımda tedavi gören hastaların \%50'sinin duyusal yüklenme yaşadıkları belirlenmiştir (Barnard ve Sandelowski 2001; Bergbom Engberg ve Haljamae 1988; Çınar 2010).

YBÜ'ndeki hastaların yaşadıkları önemli sorunlardan biri, zaman oryantasyon bozukluğudur. Tunçay ve Uçar (2010) hastaların \%18.9'unun gece-gündüz ayrım zorluğu yaşadığını saptamıştır. Zazpe ve ark. (1997) yapmış olduğu araştırmada, ziyaret saatlerinin sınırlı olduğu YBÜ’lerinin genellikle kapalı ortamlar olması, ünitelere kişisel eşyaların alınmaması, ziyaretin kısıtlı ya da yasak olması hastada önemli ölçüde stres ve anksiyeteye neden olabilmektedir (Tunçay ve Uçar 2010; Zazpe, Margall, Otano, Perochena ve Asiain 1997).

YBÜ'nde hastaların yaşadığı stres ve buna bağlı rahatsızlıklar bireyin sağlığı üzerinde olumsuz etki göstermekte, hastanın iyileşme sürecini uzatmakta ve hastanede kalış süresini de artırmaktadır. Bu stres ve rahatsılıklar birey YBÜ'nde yatarken ortaya çıktığı gibi başka bir servise nakledildikten ya da taburcu edildikten sonra da ortaya çıkabilmektedir (Çınar 2010; Tuncay ve Uçar 2010). Maadox ve ark. yaptıkları çalışma- 
da, bir grup hastayla YBÜ'nden taburcu olduktan sonraki 6-15. hafta içinde görüşme yapmışlardır. Kontrol grubu olarak benzer özelliklere sahip, YBÜ'nde yatmamış hastalar alınmıştır. Hastalarda ele alınan temel konuları; normal hayata dönme, rutinleri yapabilme ve YBÜ ortamının yaratabileceği olumsuz duyguları geride bırakma oluşturmuştur. Araştırma sonunda YBÜ'nde yatmanın hastaların iyileşme sürecini olumsuz yönde etkileyen faktörler arasında yer aldığı belirlenmiştir (Maadox, Dunn ve Pretty 2001).

YBÜ’nde gürültü, hastaların duyusal yüklenme yaşamalarına neden olan bir başka etkendir (Mollaoğlu 1997). Bu nedenle Fransa Ulusal Mesleki Güvenlik ve Sağlık Enstitüsü, hastanelerdeki gürültü yoğunluğunun gece boyunca $35 \mathrm{~dB}(\mathrm{~A})$ 'y1 ve gündüz boyunca $40 \mathrm{~dB}(\mathrm{~A})$ 'yı aşmaması gerektiğini önermektedir (Tunçay ve Uçar 2010). Ancak Cornock'un çalışmasında telefon sesi, tanıdık olmayan sesler ve gürültü 15 . s1rada stresör olarak tanımlanırken, Mui So ve Chan'in çalışmalarında makinelerin sesi 4. sırada, telefon sesi 35. sırada, hemşire ve hekimlerin yüksek sesle konuşmas1/gülmesi 37. sırada stresör olarak tanımlanmıştır (Cornock 1998; Mui So ve Chan 2004). Hastaların başka hastalara yapılan tıbbi işlemlere tanık olmak, diğer hastaların acı çektiğini ve kötüleştiğini görmekten rahatsız olma oranlarının göz ardı edilmeyecek düzeyde olduğu saptanmıştır. Söz konusu bu durumlar, YBÜ'sindeki hastaların stres yaşamalarına neden olan en önemli etkenlerdendir (Maadox ve ark. 2001; Mollaoğlu 1997; Tunçay ve Uçar 2010). Cornock'nun çalışmasında özbakım gücünün kendisinde olmaması, başkasına bağımlı olma hastalar için 6. sırada, Mui So ve Chan'ın çalışmasında 2. sırada stresör olarak yer almaktadır (Cornock 1998; Mui So ve Chan 2004).

YBÜ'nde hasta açısından stres yaratan durumlara ilişkin hastaların ve hemşirelerin görüşlerinin saptandığ1 çalışmalarda hemşirelerin ilk sıralarda tanımladıkları stresörlerin hastaların siralamasından farklı olduğu ve hemşirelerin hastalar için stresör olarak belirledikleri durumların genellikle hemşirelik girişimleriyle değiştirebilecekleri durumlar olduğu saptanmıştır (Cornock 1998; Maadox 2001). Bu nedenle hemşire, hastaya ba- kım verirken ve çevresini düzenlerken hastanın görüşlerini ve önceliklerini belirlemelidir. Hastanın çevresine yönelik algılarını, stres kaynaklarını ve stres durumunda gösterdiği tepkileri çok iyi değerlendirmeli, bu doğrultuda hastanın çevresini düzenlemeli ve önlemler almalıdır. Hastanın bakımında, hastada rahatsızlığa neden olan faktörlerin ortadan kaldırılması ve azaltılmasına yönelik önlemler alınması, hastada ortaya çıkabilecek uykusuzluk, yer-zaman oryantasyon bozukluğu, duyusal değişiklik gibi problemlerin görülme sıklığı ve YBÜ sendromunun gelişme riskini azaltır. Dolayısıyla hastanın kendisini daha rahat ve güvende hissetmesini, iyileşme sürecinin hızlanmasını ve YBÜ'nde kalış süresinin kısalmasını sağlar (Çınar 2010; McKinley, Coote, Parbury 2002; Tunçay ve Uçar 2010).

Yoğun bakım üniteleri iletişim güçlüklerinin yaşand1$\breve{g} 1$ birimlerdir. Hastalar, aile üyeleri ve arkadaşlarıyla birlikte olamadıkları ve alışkanlıklarını sürdüremedikleri için yalnızlık ve izolasyon duyguları yaşayabilmekte, aynı zamanda monitör sistemlerinin, ventilatörlerin, sıvı ve/veya ilaç infüzyon pompalarının sesleri nedeniyle anksiyete yaşamakta ve değişik derecelerde psikolojik desteğe ihtiyaç duymaktadırlar (Alasad ve Ahmad 2005). İletişim problemleri hastada büyük bir huzursuzluğa, tedavi ve bakımı yapan kişide strese neden olur (Cornock 1998; Öz 2004). Hemşireler, iletişimi hastanın gereksinimlerini belirlemek ve karş1lamak amacıyla kullanmaktadırlar. Hastanın gereksinimlerinin karşılanması, bakımına katılımının sağlanması, hastaya yapılan işlemlerin açıklanması; özgüvenin ve özsaygının artmasını, anksiyete ve korkusunun azalmasını sağlar (Kutlu 2010). Hastaya açıklama yapılması etik bir sorumluluk olduğu kadar, hastanın uyumunu kolaylaştırması ve yoğun bakımın olumsuz etkilerinin azaltılmasını sağlaması açısından da önem taşımaktadır (Terakye 1994). Açık ve anlamlı iletişim, hastanın stresinin, korku ve konfüzyonunun azaltılmasını sağlar. Hastanın bilinci kapalı olsa bile iletişim sürdürülmelidir (Çınar 2010). Efil ve ark. (2001) çalışmalarında uygun iletişim yöntemi kullanıldığında hastaların anksiyetelerinin azaldığ 1 ve tedaviye uyumlarının arttığı gözlemlenmiştir (Efil, Kurucu ve Eser 
2001). Literatürde yapılan çalışmalar sedatize ve bilinci kapalı hastaların konuşulanları anladığını ortaya koymakta, hastaya uygulanacak medikal girişimlerin, hasta ile sözel iletişim miktarını artırdığını ortaya koymaktadır (Çınar 2010; Efil ve ark. 2001). Yine Efil ve ark. (2001) bilinci kapalı hasta ile yapılan sözel ve dokunma ile iletişimde hastanın gözlerinde onaylama şeklinde anlamlı yanıtı oluşturduğunu belirtmişler, hasta konuşmaya başladıktan sonra hastanın konuştukları çoğu şeyi anlatarak; bilinci kapalı iken konuşulanları anladığını da ortaya koymuştur. Literatürde vurgulandığı gibi hemşirelerin bilinci kapalı hasta ile iletişime ilişkin yeterli bilgi ve beceriye sahip olması ve uygulaması nitelikli hemşirelik bakımının sağlanmasında önem taşımaktadır. Dolayısıyla sağlık hizmetleri sunumunu da olumlu yönde etkileyecektir (Çınar 2010; Efil ve ark. 2001).

Alasad ve Ahmad, hemşirelerin yoğun bakım ünitesinde bilinçsiz hastalarla daha az sıklıkla iletişim kurduklarını, Baker ve Melby, yoğun bakım hemşirelerinin yalnızca \%5'inin bilinçsiz hastayla iletişim kurduklarını, hastayla kurulan iletişimin içeriğinin ise hastaya uygulanacak işlemleri açıklamak için olduğunu belirtmişlerdir. Aynı çalışmada, bilinçsiz hastalarla kurulan iletişime ayrılan zamanı belirleyen en önemli faktörlerin hastaların bilinç düzeyleri, fiziksel bakım gereksinimleri ve akrabalarının varlığı olarak belirlenmiş̧ir (Alasad ve Ahmad 2005; Baker ve Melby 1996). Yap1lan çalışmalar, yoğun bakım hemşirelerinin teknik konular üzerine odaklandıklarını bilinci kapalı hastaların psiko-sosyal gereksinimlerini karşılamada yetersiz olduklarını ve etkisiz iletişim kurduklarını göstermektedir (Çınar 2010). Buna karşın, yapılan birçok çalışma, uyaranlara cevap vermeyen hastaların çevresinde konuşulanları işitebildiğini göstermektedir (Alasad ve Ahmad 2005; Baker ve Melby 1996; Çınar 2010). Lawrence (1995), bilinçsiz hastalık öyküsü olan 100 hastanın, sağlık ekibi çalışanlarının hastaların farkında olmadığını varsaydıkları halde, nasıl duyduklarını, anladıklarını ve duygusal yanıtlar verdiklerini tanımlayarak bilinçsiz hastalarla sözel iletişim kurmanın gerekliliğini belirtmiştir.
Dokunma, hemşire hasta etkileşiminde önemli bir rol oynar. Hemşireler yoğun bakım ünitelerinde dokunmayı hasta gereksinimlerine göre bilinçli ve amaçlı olarak kullanmalıdır. Terapötik dokunma çeşitlerinden ekspresif dokunma; duyguları dokunarak anlatma biçimidir (Çınar ve Khorshid 2003). Ekspresif dokunmada temasin etkisiyle deri yüzeyindeki enerjinin harekete geçirilmesi söz konusudur (Çınar ve Khorshid 2003). Literatürde, dokunma ile oluşan enerji transferinin kandaki oksijen miktarını artırabileceği bu nedenle çalışmalarda, oksijen emiliminin en hassas ölçümü olarak hemoglobin değerinin belirlenmesi gerektiği ifade edilmektedir ve terapötik dokunmanın ilaç kullanmaksızın önemli ölçüde rahatlık sağladığını belirtmektedir (Arslan 2007; Arslan ve Özer 2010; Efil ve ark. 2001). Dokunmanın, yoğun bakım hastalarında anksiyetenin fizyolojik göstergelerini düzenlemede, kas gerilimini azaltmada da yararlı olduğunu gösteren birçok çalışma bulunmaktadır (Arslan 2007; Ç1nar ve Khorshid 2003; McKinley, Coote ve Parbury 2002; Mollaoğlu 1997; Wilkinson ve Simpson 2002). Yoğun bakım ve koroner bakım ünitesinde sözel iletişimde bulunan hemşirelerden hastanın koluna dokunarak iletişimi pekiştirmelerini istemiş ve bu hastaların girişimlere daha fazla yanıt verdiklerini, daha az anksiyete hissettiklerini, daha çok sözel ve sözel olmayan ifadeler kullandıklarını saptamıştır (Çınar 2010; Çınar ve Khorshid 2003).

Almerud, Updike, Wong, yoğun bakım ünitesinde yatan hastaların bütüncül bakımını destekleyici bir hemşirelik girişimi olarak müzik terapiyi önermektedirler (Almerud ve Petersson 2003; Updike 1990; Wilkinson ve Simpson 2002). Müzik terapi, hastaları tedavi sırasinda fizyolojik ve psikolojik olarak etkileyen müzik dinlemenin kontrollü şekli olarak tanımlanır (Arslan ve Özer 2010). Hastanın kültürel yapısına, dini inançlarına, yaşına uygun olarak seçilen, hoşlandığı bir müzik ya da ziyarete gelemeyen yakınının sesi kayıttan dinletilebilir. Müzik terapisinin; anksiyete ve stresin azaltılmasında, ağrı ve rahatsızlığın ilaç dışı kontrolünün sağlanmasında, duygu durumda olumlu değişiklerin sağlanmasında ve hastanede kalış süresinin k1- 
saltılmasında rolü vardır (Updike 1990; Wong, LopezNahas ve Molassiotis 2001). Müziğin yoğun bakım hastalarında; solunumu düzenlemede, kan basıncını ve kalp hızını düzenlemede, kas gerilimini azaltmada yararlı olduğunu gösteren birçok çalışma bulunmaktadır (Çınar 2010; Updike 1990; Wong ve ark. 2001).

Chan ve ark. (2006) yaptıkları çalışmalarında, müzik grubu ile kontrol grubu son-test ölçümleri karşılaşt1rıldığında kan basıncı değerlerinde istatistiksel olarak anlamlı fark bulunmuştur. Moore ve Wilkins çalışmalarında da YBÜ'de yatan hastaların müzik terapi öncesi ve sonrası nabız, solunum, ağrı ve kan basınc1 değerlerini karşılaştırmış, sonuçta nabız, solunum, ağrı puan ortalamaları arasındaki farkın anlamlı olduğu gözlenmiştir (Wilkins ve Moore 2004).

Aromaterapi, bitkisel öz yağlarla yapılan bir tamamlayıcı tedavi yöntemidir. Literatürde aromaterapinin duyusal yoksunluğu gidermek için verilen hemşirelik bakımında önemli yeri olduğu belirtilmektedir (Arslan ve Özer 2010; Margo ve Halm 2008). Woolfson ve Hewitt'in YBÜ'de; 3 gruplu 36 hasta ile yürüttükleri randomize kontrollü çalışmalarında; hastalara 5 hafta boyunca haftada 2 kez 20 dakikalık ayak masajı uygulanmış ve lavanta masajı uygulanan gruptaki hastaların nabızlarında düşme saptanmıştır (Woolfson ve Hewitt 1992). Arslan'in YBÜ' nde yatan hastalarda yürüttüğü çalışmada aromaterapinin hastaların, nabız, kan basıncı ve solunum değerlerine etkisi araştırılmış ve sonuçta gruplar arası son test değerleri karşılaştırıldığında deney grubunun nabız değeri daha düşük saptanmıştır (Arslan 2007).

\section{Duyusal Girdi Sorunlarında Hemşirelik Yaklaşımları}

Bütün hastalar duyusal yoksunluğa ve yüklenmeye karşı hassas olmalarına rağmen, bu durumdan en çok; bilinçsiz, tepki vermeyen, duyusal yetersizliği olan, anestezi uygulanan hasta grupları ve yaşlılar etkilenmektedir (Çınar 2010; Kaçmaz 2002; Kutlu ve Yıld1rım 2001). Bu hastaların bakımında psiko-sosyal gereksinimlerin ihmal edilmemesi, tedavinin ve bakımın ekip anlayışı içinde sürdürülmesi önemlidir. Bu hastaların psikososyal gereksinimlerinin göz ardı edilme nedenleri, bakımı verenlerin prognozu umutsuzca değerlendirmesi ve tepki vermeyen hastaların bilinçsiz hasta olarak yorumlanmasıdır. Ancak bu tür bir değerlendirmenin gerçek olup olmadığı henüz kanıtlanamadığı için en iyi yaklaşım "Bilinçsiz hasta yoktur" varsayımıdır (Çınar 2010; Kutlu 2010; Mollaoğlu 1997). $\mathrm{Bu}$ yaklaşım tepkisiz hastalar için tedavi edici duyusal girdi sağlamanın yollarından biridir. Tepki vermeyen hastalar için uygulanacak girişimler, anlamlı duyusal uyaranları içeren bir çevrenin bilinçli bir şekilde oluşturulması ve hastanın fiziksel bakımını içerir (Ç1nar 2010; Kaçmaz 2002; Kutlu 2010). Sağlık çalışanlarının, hastalığın seyrini umutsuzca değerlendirmeleri ve tepki vermeyen hastaları, bilinçsiz olarak yorumlamaları, bu hastaların psikososyal gereksinimlerinin göz ardı edilmesine neden olur. Bilinçsizlik, uygun motor yanıtın ve duyusal uyanıklılığın olmamasıdır. Oysa tepkisizlik, motor ve duyusal koordinasyonun sağlanamamasıdır (Arslan 2007; Shih 1997). Bu nedenle hemşire, özellikle tepki vermeyen hastalara büyük özen göstermeli, onların sesi, gözü, kulağı olmalıdır. Hemşireler hastanelerde hasta ile uzun süre birlikte olan, çalışma saatlerinin tümünü hasta başında geçiren sağlık çalışanları oldukları için, hastalara tanıdık uyaranlar vermek ve uygun duyusal uyaranları içeren hemşirelik girişimlerini planlamakla sorumludurlar (Çınar ve Khorshid 2003; Mollaoğlu 1997).

Sağlık hizmetlerinin sunumunda etkili iletişim ve ilişkilerin olumlu yönde rol oynadığı unutulmamalıdır. İletişim, birçok nedenden dolayı hayatın her yönünde çok önemlidir; stres anında duygusal destek ve bilginin karşılıklı değiş tokuşunu mümkün kılar (Çınar 2010; Elliott ve Wright 1999). Bu nedenle duyusal girdi sorunlarını kontrol altına almak için hemşireler;

- Hastalara anlamlı uyaranlar verilmeli ve tanıdık dünyası ile ilişkisi kesilmemeli,

- Bakım ve tedaviden sorumlu kişinin aynı olmasına özen gösterilmeli,

- Ailesi ve arkadaşlarının hastayı ziyaret etmeleri ve iletişim kurmaları desteklenmeli, 
- Hasta yakınları tepkisiz hastaya yaklaşım konusunda bilgilendirilmeli, hasta ile konuşma ve dokunmaları için cesaretlendirilmeli,

- Bilinç düzeyi farklı olan her hasta grubuna, yapılan işlemler hakkında bilgi verilmeli,

- Ses alarmlı monitör yerine 1 şık alarmlı monitörler tercih edilmeli,

- Sağlık çalışanları ve ziyaretçilerin yüksek sesle konuşmaları önlenmeli,

- Çok gürültülü tıbbi araç-gereç gereksiz kullanılmamal1,

- Uyku düzeni sağlanmalıdır (Arslan 2007; Kaçmaz 2002; Kutlu 2010; Moore 1989).

Hemşireler hastanelerde hasta ile uzun süre birlikte olan, çalışma saatlerinin tümünü hasta başında geçiren sağlık çalışanları oldukları için, hastalara tanıdık uyaranlar vermek ve uygun duyusal uyaranları içeren hemşirelik girişimlerini planlamaktan sorumludurlar. Bu yaklaşım için hastanın duyusal dengesini korumaya yönelik duyusal uyaranlar içinde dokunma, müzik terapi, aromaterapi, refleksoloji gibi tamamlayıc1 uygulamalara da başvurulmaktadır (Arslan ve Özer 2010).

Tamamlayıcı tedaviler, hastanın bakımını desteklemek ve yaşam kalitesini yükseltmek amaciyla tıbbi tedaviye ek olarak uygulanır. Tamamlayıcı tedavi yöntemleri; duyusal algıları harekete geçirip gevşeme etkisi oluşturarak nabız, kan basıncı ve solunum gibi fizyolojik göstergeleri düşürmenin yanı sıra, uyku bozukluğu, ağrı ve anksiyeteyi içeren yoğun bakımla ilgili komplikasyonları kontrol altına almak ya da önlemek için de etkili olabilir (Arslan 2007; Lorenzi 1999; Wilkinson ve Simpson 2002).

\section{SONUÇ VE ÖNERİLER}

Fiziksel hastalığı olan, hastanede yatarak tedavi ve bakım alan hastaya ve ailesine bütüncül bakım verilmesinde yoğun bakım hemşirelerinin psikososyal bakım ile ilgili bilgilerinin beceriye dönüştürülmesi ve uygulanmasi; hastanın duyusal girdilere uyumunu, tedavi ve bakım sürecini, iyilik halini, hastalığın seyrini, te- daviye cevabını ve morbiditeyi olumlu yönde etkileyerek hemşirelik bakımının kalitesinin de arttırılmasına katkı sağlayacaktır. Bu bağlamda, yoğun bakım hastalarında duyusal girdi sorunlarına yönelik kanıta dayalı araştırmalar yoluyla etkinliği kanıtlanmış hemşirelik girişimlerinin hasta bakımında kullanımı sağlanmalı ve bu konuda hemşireler desteklenmelidir.

\section{KAYNAKLAR}

Akdemir, N., Birol, L. (2003). İç hastalıkları ve hemşirelik bakımı. 1.basım, Vehbi Koç Yayınları, İstanbul, 23-24.

Alasad, J., Ahmad, M. (2005). Communication with critically ill patients. Journal of Advanced Nursing, 50(4): 356-362.

Almerud, S., Petersson, K. (2003). Music therapy-a complementary treatment for mechanically ventilated intensive care patients. Intensive and Critical CareNursing, 19(1): 21-30.

Arslan, S. (2007). Dokunma, müzik terapi ve aromaterapinin yoğun bakım hastalarının fizyolojik durumlarına etkisi. Yayınlanmamış Doktora Tezi, Atatürk Üniversitesi Sağlık Bilimleri Enstitüsü, Erzurum.

Arslan, S., Özer, N. (2010). Yoğun bakım hastalarının duyusal girdi sorunlarında tamamlayıcı tedaviler. Anadolu Hemşirelik ve Sağlık Bilimleri Dergisi, 13: 2.

Baker, C., Melby, V. (1996). An investigation into the attitudes and practices of intensive care nurses towards verbal communication with unconscious patients. Journal of Clinical Nursing, 5(3): 185192.

Barnard, A., Sandelowski, M. (2001). Technology and humane nursing care: (Ir)reconcilable or invented difference? Journal of Advanced Nursing, 34: 367-75.

Bergbom Engberg, I., Haljamae, H. (1988). A retrospective study of patients recall of respirator treatment nursing care factors and feelings of security/insecurity. Intensive Care Nursing, 4: 95-101.

Canl, Z. (1995). Koroner bakım ünitesinde yatan miyokard enfarktüslü hastaların anksiyete düzeyinin ve hastaları etkileyen fiziksel çevre stresörlerinin belirlenmesi. Yayınlanmamış Yüksek Lisans Tezi, Hacettepe Üniversitesi Sağlık Bilimleri Enstitüsü, Ankara.

Chan, M. F., Wong, O. C., Chan, H. L. (2006). Effects of music on patients undergoing a C-clamp procedure after percutaneous coronary interventions. Journal of Advanced Nursing, 53(6): 669-679.

Cornock, M. A. (1998). Stres and the intensive care patient: Perception of patients and nurses. Journal of Advanced Nursing, 27: 518-527. 


\section{Yoğun Bakım Hastalarında Duyusal Girdi Sorunları ve Hemşirelik Yaklaşımı}

Çınar, Ş. (2010). Bilinci kapalı hastanın psikososyal gereksinimlerini karşılamada hemşirenin rolü. 1. Temel Hemşirelik Bakımı Kongresi Kitabl, İzmir.

Çınar, Ş., Khorshid, L. (2003). Yoğun bakım hastasında terapötik dokunma. Yoğun Bakım Hemşireliği Dergisi, 7(1): 15-18.

Dedeli, Ö., Akyol, A. (2008). Yoğun bakım hastalarında psikososyal sorunlar. Yoğun Bakım Hemşireliği Dergisi, 11(1-2): 26-32.

Dedeli, Ö., Akyol, D. A. (2005). Yoğun bakım sendromu. Yoğun Bakım Hemşireliği Dergisi, 9(1-2): 20-27.

Demir, F., Dramalı, A. (2002). Yoğun bakım ünitelerinin tasarımı. Yoğun Bakım Hemşireliği Dergisi, 6(1): 8-15.

Efil, S., Kurucu, M. N., Eser, O. (2001). Beyin cerrahi yoğun bakımında takip edilen hastaların hasta yakını ziyaret sıklığının ve hemşire ile olan iletişimin hastanın iyileşmesine etkisi. Kocatepe Tlp Dergisi, 12: 151-155.

Elliott, R., Wright, L. (1999). Verbal communication: What do critical care nurses say to their unconscious or sedated patients? Journal of Advanced Nursing, 29(6): 1412.

Fontaine, D. K., Briggs, L. P., Pope-Smith, B. (2001). Designing humanistic critical care environments. Critical Care Nursing $Q u$ arterly, 24(3): 21,14.

Granberg, A., Engberg, I. B, Lunberg, D. (1998). Patients' experience of being critcally illor severely injured and cared for in an intensive care unit in reation to the ICU syndrome. Intensive and Critical Care Nursing, 14: 294-307.

Hewitt, J. (2002). Psycho-affective disorder in intensive care units: A review. Journal of Clinical Nursing, 11: 575-584.

Hunt, J. M. (1999). The cardiac surgical patient's expectations and experiences of nursing care in the intensive care unit. Australian Critical Care, 12(2): 47-53.

Kaçmaz, N. (2002). Yoğun bakım hastalarının psikolojik sorunları ve hemşirelik yaklaşımları. Yoğun Bakım Hemşireleri Dergisi, 6(2): 75-81.

Kutlu, L. (2010). Bakım ünitelerinde sağlık ekibi üyeleri, hasta ve yakınları ile iletişim. http://www.cayd.org.tr/Egitim/HemEg1.html. (26.06.2012).

Kutlu, L.,Yıldırım, A. (2001). Hastalarda duyusal yoksunluk. Yoğun Bakım Hemşireliği Dergisi, 5(2): 83-86.

Lawrence, M. (1995). The unconscious experience. American. Journal of Critical Care, 4(3): 227-232.
Lorenzi, A. E. (1999). Complementary/alternative therapies so many choices. Geriatric Nursing, 20: 125-33.

Maadox, M., Dunn, S. V., Pretty E. L. (2001). Psychosocial recovery following ICU: Experiences and influences upon discharge to the community. Intensive Crit Care Nursing, 17: 6-15.

Margo, A., Halm, M. A. (2008). Essential oils for management of symptoms in critically ill patients. American Journal of Critical Care, 17: 160-163.

McKinley, S., Coote, K., Parbury, S. J. (2002). Development and testing of a faces scale for the assessment of anxiety in critically ill patients. Journal of Advanced Nursing, 41(1): 73-79.

Mollaoğlu, M. (1997). Kritik bakım ünitelerinin duyusal girdilere etkileri ve hemşirelik girişimleri. Yoğun Bakım Hemşireleri Dergisi, 1(2): 86-90.

Moore, T. (1989). Sensory deprivation in the ICU. Nursing, 3(36): 44-47.

Mui So, H., Chan, D. S. K. (2004). Perception of stresssors by patients and nurses of critical care units in Hong Kong. International Journal of Nursing Studies, 41(1): 77-84.

Öz, F. (2004). Sağlık Alanında Temel Kavramlar. 1. basım, İmaj İç ve Dış Ticaret AŞ., Ankara.

Phipps, W. J. (1991). Medical-Surgical Nursing. 4th ed., Mosby-Year Book Inc., USA.

Shih, F. (1997). Perception of self in the intensive care ünit after cardiac surgery among adult Taiwanese and American-Chinese patients. International. Journal of Nursing Studies, 34(1): 17-26.

Terakye, G. (1994). Bilinci Kapalı Bireyle Illetişim. 1. basım, Aydoğdu Ofset, İstanbul.

Tunçay, Y. G., Uçar, H. (2010). Hastaların yoğun bakım ünitesinin fiziksel ortam özelliklerine ilişkin görüşleri. Hacettepe Üniversitesi Sağllk Bilimleri Fakültesi Hemşirelik Dergisi, 33-46.

Updike, P. (1990). Music therapy results for ICU patients. Dimensions of Critical Care Nursing, 9(1): 39-45.

Wilkins, M. K., Moore, M. L. (2004). Music intervention in the intensive care unit: A complementary therapy to improve patient outcomes. Evidence- Based Nursing, 7: 103-104.

Wilkinson, J. M., Simpson, M. D. (2002). Personal and professinol use of complementary therapies by nurses in NSW, Australia. Complementary Therapies in Nursing \& Midwifery, 8: 142-147. 
Wong, H. L. C., Lopez Nahas, V., Molassiotis, A. (2001). Effects of music therapy on anxiety in ventilator dependent patients. Heart \& Lung, 30(5): 376-387.

Woolfson, A., Hewitt, D. (1992). Intensive aromacare. International Journal of Aromatherapy, 4(2): 12-13.

Yıldırım, İ., Atalay, M. (1992). Cumhuriyet Üniversitesi Uygulama ve Araştırma Hastanesi'nde yatan yetişkin hastaların hastane gürültüsünden nasıl etkilendiklerinin belirlenmesi. III. Ulusal Hemşirelik Kongre Kitabl, 24- 26 Haziran, Sivas.

Zazpe, C., Margall, M. A., Otano, C., Perochena M. P., Asiain, M. C. (1997). Meeting needs of family members of criticaly ill patients in a spanish intensive care unit. Intensive Critical Care Nursing, 13: $12-16$. 